\title{
大気污染と酸性雨現象
}

\section{Acid Deposition -Atmospheric Processes in Japan-}

\section{1.はじめに}

大気污染の程度を評価するためには，都市部におけ る $\mathrm{NOx}$ や SOx あるいは粒子状物質濃度等の現況とそ の長期的傾向を把握するとと以外に，乙れらの污染物 質が発生源または一般環境中で他の有害物質に姿を変 えていないか，あるいは濃度は低くとも本来清浄であ るべき都市部の背後地域にまで活染が拡大されていな いかを調べるとともまた重要である.

てれらのてとを考慮してみると，乙て数年の大気污 染の主要な課題には，NOxを中心にした自動車排ガス， 光化学スモッグに代表される二次的污染物質, 質と量 の両面から把握すべき粒子状物質, さらには, 地球的 (グローバル)な規模の污染が含まれると考えられる.
玉 置 元 則*

近年，北欧・北米を中心にして社会問題となってい る雨水の酸性化：酸性雨現象には, てれらの大気污染 の課題が濃縮して含まれているように思われる.

従来，降雨は大気污染物質认対する浄化作用を果す とのみ考えられていたが，今日では，それが同時に雨 水自体の污染之土䁃・水圏等への污染を伴うと考えら れるようになってきた。

大気污染が進行し, 雨水が污染され, 雨水の質的変 化が起る。乙のことは単に雨水の酸性化の問題だけに は止らないが，北欧・北米で進行している酸性雨によ る深刻な生態系の破壊を考えるとき，酸性雨現象を解 明し，その対策を構じることは，大気の污染と雨水の 質的変化を防ぐために，極めて重要であり，かつ急務 と考えられる1 6).

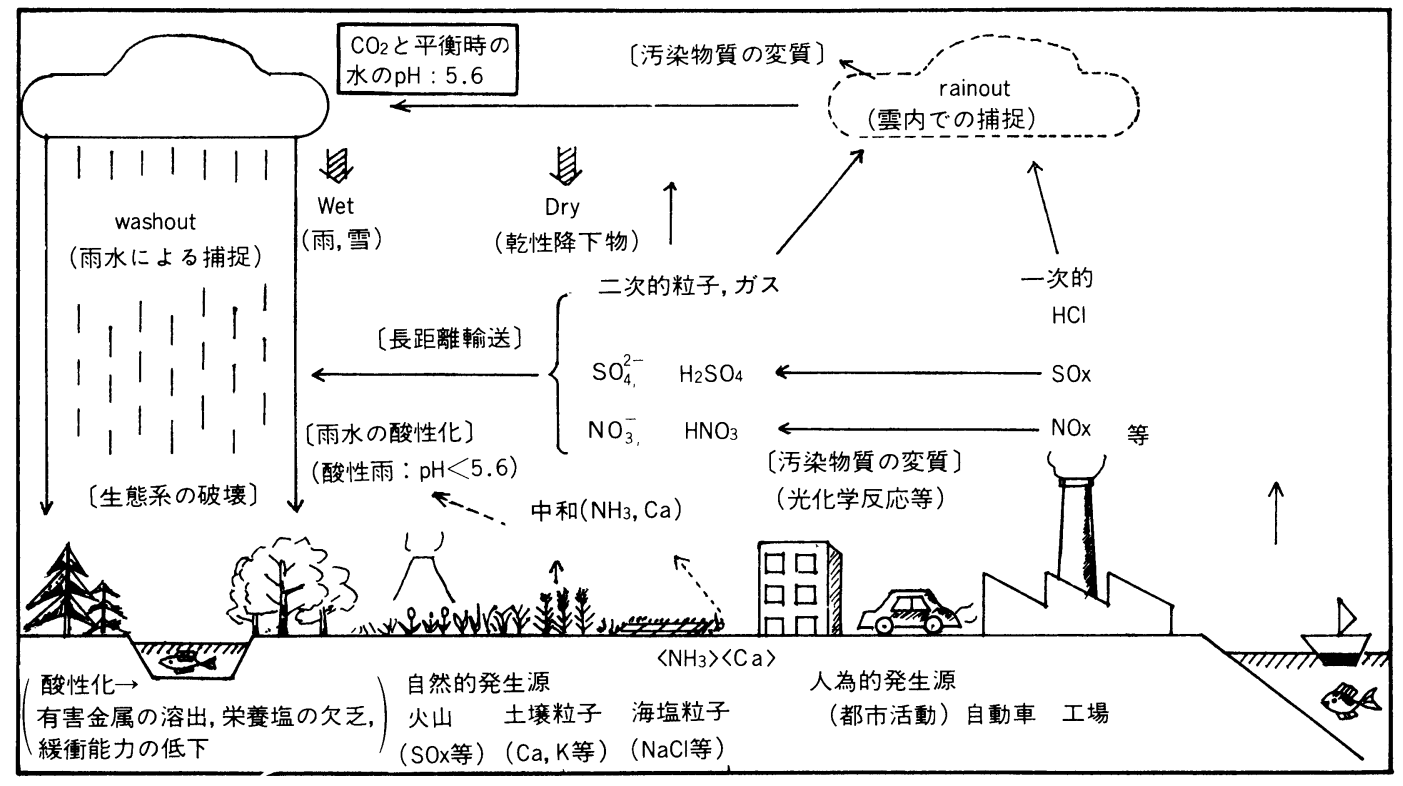

図-1＼cjkstart酸性雨現象のメカニズム

\footnotetext{
*兵庫県公害研究所, 主任研究員, 工博 Motonori TAMAKI
} 


\section{2. 酸性雨現象とは何か}

\section{1 酸性雨現象により顕在化した大気污染の影響の 多様性と広域化}

雨水の酸性化：酸性雨現象は, 北欧・北米では, 主 に湖沼水の酸性化に基づく魚介類の死隇ならびに土壌 の酸性化に基づく森林被害を伴う生態系の破壊へと進 行している.乙の酸性雨現象によって, 大気污染の広 域的な低濃度慢性曝露の影響に目が向けられるように なるとともに，降雨の大気污染物質に対する浄化機能 についても関心が強められている(図-1).

近年, 都市部周辺の大気污染自体は軽減されたかも しれないが，より広域的な污染としてひろがっており， さまざまな地域でその影響が現われている，その一つ の形態が酸性雨現象である. 自然の浄化作用はあるも のの, 排出された污染物質に見あう量が, 環境中に蓄 積される. その警告として「酸性雨」があるのかもし れない.

本来, 大気污染は人間とそれをとりまく環境全体の わく内で把握されるべきあのであり, 酸性雨現象によ って, 都市部周辺での影響から, 後背地も含めた環境 全体への污染の拡大に目がむけられるようになったと 言えよう. したがって, 酸性雨を含む雨水の質的変化 は, $\mathrm{CO}_{2}$ 濃度増加による地球の温度上昇, 八ロカーボ ン, $\mathrm{N}_{2} \mathrm{O}$ 等による成層圏のオゾン層破壊等のグローバ ルな課題と類似の内容を有している.

なお, 酸性雨の内容を規定するのは, 大気污染物質 の長距離輸送, 污染物質の変質, 雨水の酸性化, 生態 系破壊の 4 つの特徴である.

\section{$2.2 \mathrm{pH}$ による雨水の評価}

「酸性雨」で表現されるように, 大気污染物質に基 づく雨水の質的変化は主に酸性度によって評価され, 指標としてpHが用いられている.

雨水が大気中の炭酸ガス等と平衡を保つ酸性度はpH 5.6 程度である. 大気中には，雨水をアルカリ性側に 導びくと考えられる物質も存在するため, 厳密にはpH $\fallingdotseq 5.6$ を雨水のバックグラウンド値と言えない点があ るあのの, 現在, pH 5.6以下の雨水は広い意味で「酸 性雨」とされている. このなかでも, 主に“被害”に結び つくのはpH 4 以下の強酸性の雨であり, 我が国では $\mathrm{pH} 2.6$ という極めて低い $\mathrm{pH}$ 示す雨水む観測されて いる. しかし， pH4 以上であっても，酸性化した降 雨に長時間継続して曝露され蓄積されれば, その影響 は大きいものと思われる.
こてで注意しておかなければならないのは, pH は 指標値であり，例えば $\mathrm{pH} 4$ と $\mathrm{pH} 5$ は值の上では 1 の 差であるが, 水素イオン $\left(\mathrm{H}^{+}\right)$濃度にすれば10倍の違 いがあり, 一般の污染物質濃度の表示, $1 \mathrm{ppm}(\mathrm{ppb})$ や $1 \mu \mathrm{g} / \mathrm{m}^{3}$ と異なる点がここにある.

雨水の質的変化の程度は, 雨量とそして溶解してい る各種有害物質の濃度から総合的に判断すべきである. しかしながら，一般的には，乙のように雨水の酸性度 $(\mathrm{pH})$ で評価されている. てれは燃焼によって生成され るSOxやNOxのような気体状物質あるいは，その大気 中での二次生成物が主に酸性の性状を有しているてと, 動植物に与える総合的な影響ならびに測定の簡便さか ら考えて，指標として妥当であると思われる。

\section{3 雨水に主に含まれている物質}

通常の雨水は河川水や湖沼水とほぼ同じ性状をして いるが, $\mathrm{pH}$ のみが低いのが特徴である. 河川水や湖 沼水の $\mathrm{pH}$ は 7 亿近い值を示すが, 都市部周辺の雨水 のpHはおよそ 4.5 である.

大気中のほとんどの污染物質は程度の差はあれ，降 雨により洗浄されるため, 雨水中には, 工場あるいは 自動車の人為的発生源ならびに土壌, 海塩粒子等の自 然的発生源から発生される污染物質がほとんど検出さ れる.

我が国の都市部周辺で測定されたデータからは, 雨 水中のアニオンの総量に占める $\mathrm{SO}_{4}{ }^{2-}, \mathrm{NO}_{3}{ }^{-}, \mathrm{Cl}^{-}$の 割合は高い. これらはそれぞれ大気中のSOx, NOx, $\mathrm{HCl}(\mathrm{NaCl})$ 等からもたらされる。 また，力チオンの 総量に占める $\mathrm{H}^{+}, \mathrm{NH}_{4}^{+}, \mathrm{Na}^{+}, \mathrm{Ca}^{2+}, \mathrm{Mg}^{2+}$, $\mathrm{K}^{+}$の割合も高い. 雨水の酸性化に影響を及ぼす雨水 中成分は主要には, これら10種足らずの成分と考えて よさそうである。

$\mathrm{pH}$ 以外に, 雨水の污染度を知る尺度として, 我が 国では導電率が多く測定されている。乙れには雨水中 のイオンの挙動が反映されるため, この值から雨水中 のイオン性物質の総量に関する知見が得られる.

$\mathrm{pH}$ はカチオンとアニオンのバランスによって决ま るため, 同じ $\mathrm{pH}$ の雨であイオン強度, 導電率が異 なることが多く，イオン強度の小さな雨水であ低い $\mathrm{pH}$ を示す場合がある．したがって，土壌あるいは生態系 へのインパクトを考える場合には，指標としての $\mathrm{pH}$, 指標としての導電率の両者を組み合わせて見て行く必 要がある.

また，酸性化は雨水だけではなく，雪も同じで，特に 雪に溶けてんだ物質は, 春先に一挙に溶け出るため, 
生態系に急激な影響を与えるアシッド・ショックとい う現象が起る.さらに雨水や雪(Wet)だけではなく, 乾性の酸性降下物(Dry)による影響む同様に大きく, てれをも含めて酸性降下物としてとらえた方がよいよ うに思われる. Dryの影響には, 一度植物に付着し, そこに降雨があった場合に, 雨水をより酸性化させる ステム・フローという現象も含まれる。

\section{4 雨水成分の指標性}

雨水の酸性化の指標は $\mathrm{pH}$ でなされており, 雨水成 分のなかでは $\mathrm{NO}_{3}$-の方が $\mathrm{SO}_{4}{ }^{2-}$ より雨水の質的変化に 対する指標性を, より有する傾向がある. てれは, $\mathrm{SO}_{4}{ }^{2-}$ の方が時系列的にも地域的にも濃度变動が小さいため である.さらに, $\mathrm{Ca}^{2+} \mathrm{Mn}^{2+}$ あ雨水污染の指標と なる。

一方, 雨水成分を用いて大気污染の評価を行うこと ができる.とりわけ, 大気中のNOx濃度とその化学反 応が明らかにされるにつれ, 雨水の酸性化との関係が 注目されるようになってきており, 雨水中の $\mathrm{NOx}$ 系污 染物質は大気污染評価の有効な指標となりうる.

その指標は, 現在, 大気中の個々の物質の濃度をも とにしてなされている大気污染の評価を総合的評価と して行う指標として, また, 長距離輸送に伴う気塊の 性状変化の指標として, 更には, 地上では測定しえな い上層の大気污染物質の分布状態の指標として有意義 である。

\section{5 雨水測定における採取法統一の重要性}

大気污染物質の測定に押いては, 標準物質の発生・ 調製方法とともに試料の捕集法は極めて重要である. 気体状物質に扔いては, 特殊・選択性を有する吸収液, 吸着剂に工夫がてらされてきたし, 粒子状物質におい ては, 捕集剤としての沪紙の材質やインパクターの性 能の改善に努力がはらわれてきた。 雨水成分の測定に おいても, 採取法(捕集法) は極めて重要である。

大気中の污染物質の多くは降雨と降塵により除去さ れる. そのため, 雨水の採取法でも, 降雨時のみ雨水 を採取するWet only (湿性降下物, 雨十雪) の採取と 非降雨時の乾性降下物(Dry) も含めて採取する, Bulk の採取あるいはDryとWet別の採取がある. Bulkの採 取は手間がかからないが, 得られる情報量は制限をう ける。

また, Wet only の採取では, 降雨時のみふたが開 くよう，ふたの開閉が自動化されている装置が多く用 いられている. Wet onlyの採取では, 一雨毎(Event) に全量採取する方法と雨水を分割採取する方法(分取)
に分けられる，分取では，主に容量別分取と時間別分 取に分けられるが，我が国では前者の使用が多い。ま た, 一日単位での採取も行われている.ささらフロー システムで連続的に雨水の $\mathrm{pH}$ や導電率が測定される 自動測定器屯開発されている.

我が国では, 酸性雨問題が主に“人体被害”いう形で 登場したことから, 降雨初期の雨水の性状の把握が重 要視されたため, 初期降雨の容量別採取の装置が主に 使用されてきた。それに対し, 北欧・北米では生態系 に対する影響が中心課題であり, 長期的なデー夕の蓄 積のために, 一雨全量採取あるいはWet onlyやBulk による一か月単位の採取が主に採用されてきた。

このようにして採取された雨水について電極法によ り $\mathrm{pH}$ が測定され, イオンクロマト法, 原子吸光法, 比色法等により種々のイオン性成分が分析されている.

雨水の污染の現状を正しく把握し, 污染機構を明ら かにするためには，科学的に厳密な統一性ある測定法 の確立が望まれる。 今, 我が国で一番求められている ことは，同一方法で採取した雨水を同一方法で分析す るととによって得られる, 国際的評価偡えうる，互 換性のあるデー夕の蓄積である.

\section{3. 雨水酸性化のメカニズム}

\section{1 降雨による大気污染物質の浄化作用}

吸収・吸着, 化学反応あるいは拡散による除去もあ るが, 都市部で長期間大気が停滞し, 降雨が無いとし たら, 大気の污染の程度ははかりしれないあのになる だろう。

大気污染物質の大気中での浄化(除去)過程としては, 1) 降雨, 降塵, 2) 有害な二次的物質への変化, 3 ) 植物, 物質表面への吸収・吸着, 4) 上層での分解, 5 ) $\mathrm{N}_{2}, \mathrm{O}_{2}$ 等無害物質への変化等が考えられるが, 5 )の過程を除いては, 何らかの形で動植物への悪影 響が䯚念される。

てのような大気を浄化する一過程が一方では酸性雨 をむたらしているのであるが, 大気の浄化という立場 から考えた場合，降雨による污染物質の除去作用は一 様でないてと,ならびにその能力には限界があること は当然である.

大気中には浄化されにくい污染物質が多数存在する. たとえば, 窒素酸化物系の污染物質では, 二次的生成 物である気体状硝酸 $\left(\mathrm{HNO}_{3}\right)$ や粒子状硝酸塩 $\left(\mathrm{NO}_{3}{ }^{-}\right)$ の方が一次污染物質である NOx よりも雨水に取り込 まれやすい傾向を示し, $\mathrm{NOx}$ の中では $\mathrm{NO}_{2}$ の方が雨 
水に溶け込みやすく, NO は雨水による洗浄作用をほ とんど受けない.

NOx 系污染物質の雨水による捕捉率が, 一次污染 物質に対してよりも，その二次的生成物に対して高い ことは, 大気中のNOxの循環系の解明の点から考える と, 重要な示唆をしているように思われる.

\section{2 大気污染物質の雨水への取り込み過程}

大気污染物質が降雨により浄化される際の, 雨水へ の取り込み過程は大きく分けて二つある。一つは雲内 に取り込まれる過程であり, rainoutと言われ, 長距 離輸送された污染物質も多く取り込まれる。一方, 降 雨が始まり, 雲の下で雨滴に取り込まれる污染物質の 除去過程はwashout之言われ，主にその地域の大気污 染物質を洗浄する.

乙の両者の污染物質に対する作用機序は異なるが, 現在のところ, 雨水の酸性化に及ぼす両者の寄与率の 地域的特性は明らかにされていない.

気体状物質の雨水への取り込みは, 雨滴に対する溶 解度等によって決められ, 温度, $\mathrm{pH}$, 共存イオンの影 響を受けやすい，気体状物質の多くは，雨水中で相当 するイオンに変化するが， $\mathrm{N}_{2} や \mathrm{O}_{2}$ のように気体状の まま存在したり, $\mathrm{CO}_{2}$ のように雨水中のイオンと大気 中のガスとの平衡関係になるものあある.

一方，粒子状物質は粒径の大きいものほど慣性衡突 により雨滴に取り込まれやすいが，粒径が非常に小さ くなると, 今度はブラウン運動により雨滴に取り込ま
れやすくなる。一番捕捉されにくい粒子の粒径は 0.1 $\mu \mathrm{m}$ 付近と考えられている(Green field gap).粒子状 物質に含まれている可溶性成分は雨水中にイオンとし て溶け出すが, 不溶性成分として雨水中に存在するも の屯少なくない、 $\mathrm{Na}$ 等はほとんど前者であるが, $\mathrm{Ca}$ 等は両者の形で存在し, Feは後者が多い.

このようにして, 取り込まれた大気污染物質の中に は, 雨水中で新たな化学反応等を起すすのあ少なくな い.

\section{3 雨水の酸性度を決める物質}

都市部周辺の雨水の酸性度は, 前述の $\mathrm{pH} \fallingdotseq 5.6$ 亿相 当する酸性度に，化石燃料の燃焼等によりもたらされ る一次的, あるいは大気中の化学反応等に伴う二次的 な酸性物質の溶解によって上積みされる。一次的な物 質としてはSOx, $\mathrm{NOx}, \mathrm{HCl}$ 等が主に指摘されており, 二次的物質としては, 主に大気中の光化学反応で生成 される $\mathrm{H}_{2} \mathrm{SO}_{4}\left(\mathrm{SO}_{4}{ }^{2-}\right), \mathrm{HNO}_{3}\left(\mathrm{NO}_{3}{ }^{-}\right)$, あるいはアル デヒド類, 過酸化物等があげられている.

雨水の酸性化は, 初期には大気中の污染物質の濃度 から推定して，ほとんどSOxあるいは $\mathrm{SO}_{4}{ }^{2-}$ に原因し ていると考えられていたが, 近年, 大気中のNOxの挙 動が明らかにされるにつれ, 雨水中に $\mathrm{NO}_{3}$-イオンを与 える $\mathrm{NOx}$ あるいは $\mathrm{HNO}_{3}$ の役割が重要視されだした (図-2).

たとえば，McNaughton は米国での測定データの 解析から, 雨水の $\mathrm{pH}$ は主要にはSOxによって規定さ

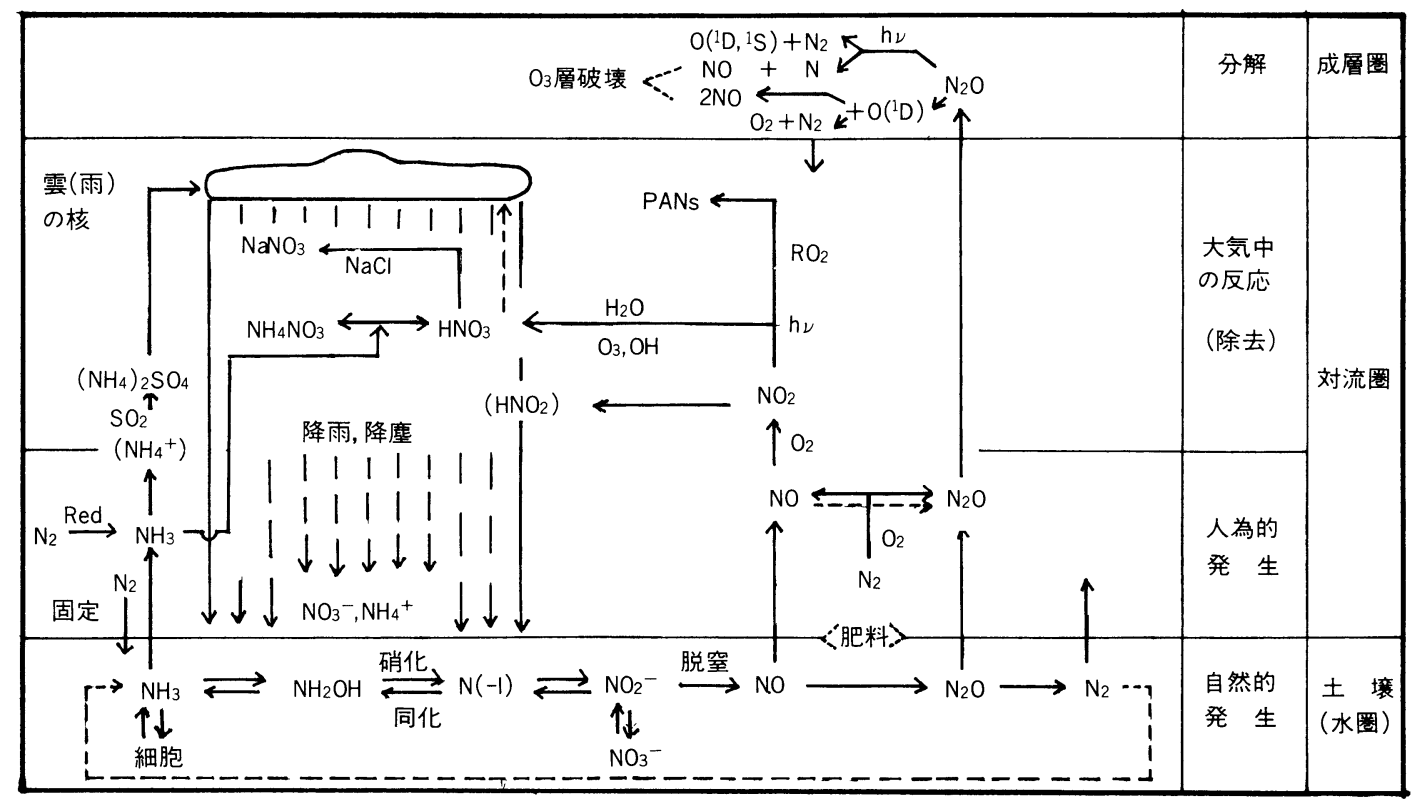

図-2 大気中の窒素化合物の循環過程 
れるが，季節によってはNOxの果す役割の大きいて とを示している. 一方, Galloway等は, 米国北東部 での年平均値から, 雨水の酸性度に対する $\mathrm{H}_{2} \mathrm{SO}_{4}$ と $\mathrm{HNO}_{3}$ の最大寄与率を求め, 1964 1979年の 15 年間 に $\mathrm{HNO}_{3}$ の役割は $\mathrm{H}_{2} \mathrm{SO}_{4}$ の役割に対して約 $50 \%$ 増加 したてとを示し, $\mathrm{HNO}_{3}$ の役割の增大の根拠として化 石燃料の使用に伴う NOx の増加ならびにその NOxが SOx より相対的に量が増加したてとをあげている。

Durham 等の計算結果では, $\mathrm{HNO}_{3}$ の吸収により 雨水の酸性化が大きく進むととが示されている.

このような雨水中の $\mathrm{NO}_{3}{ }^{-}$イオンの增加ならびに 低 $\mathrm{pH}$ 雨水中で $\mathrm{NO}_{3}$-イオンが高濃度になるとと は, 米国のロスアンゼルス近郊でも,さらには我が 国でも観測される例が多く, $\mathrm{HNO}_{3}$ を含む $\mathrm{NOx}$ 系污 染物質が，大気のみならず，そてを落下してくる雨水 の質的変化をむたらし，酸性雨現象に大きな役割を果 している.

\section{4. 污染の広域化と生態系の破壊}

\section{1 大気污染物質の長距離輸送}

欧米では「酸性雨」は非常に古くから社会的な問題 となって打り，すでに19世紀後半から，科学者によっ て, acid rain という言葉が使われ，その扔扔よその 性状と特徴か指摘されていた。 そして, てれらは工場 における化石燃料の使用によるものであると把握され ていた。

1960年代に入ると，スカンジナビア諸国の酸性雨の 原因が, 数百〜数千 $\mathrm{km}$ 離れた欧州各国から長距離輸 送されて, 移流してくる大気污染物質にあり, 酸性雨 は広域的な現象であることが示されるようになった。 このことも大きな理由の一つとなり，第 1 回国連環境 会議がストックホルムで開催された。また，UNEP (国連環境計画)特別会議が「ナイロビ宣言」をまとめ, そのなかで「酸性雨等の大気の変化は, 人間環境に対 して一層深刻な劦威となっている」とし, 開発途上国 と一部先進国の大気污染抒よび長距離輸送の問題がク ローズアップされたととは記憶に新しい.

てのような国境を越えた污染物質の長距離輸送に基 づく酸性雨の実態を正しく把握し，その原因を究明し 対策をたてるため，関係各国の協力が必要になってい る. 欧州ではOE C D (経済協力開発機構)のLRTAP 計画あるいは全欧を含むEMEP計画に扔いて, 100 か

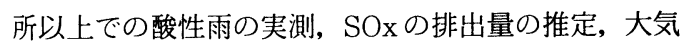
污染物質の長距離輸送モデル研究, 移動量の試算等が
国際的な取り組みとして行われてきた。

同様の污染物質の長距離輸送に基づく雨水の酸性化 は北米・カナダでむ指摘されている.

米国では，1980年に Acid Precipitation Actが成 立し, てれに基づく報告書では, 酸性雨の主要な原因 を人為的理由による SOx と NOx 亿帰している.また， 米国一カナダ間では酸性雨の越境污染に対処する「越 境大気污染仪関する会議覚書」が締結され，1986年 3 月には, レーガン・マルルーニー会談で, カナダが主 張してきた「カナダの酸性雨禍は米国で排出された S O $\mathrm{O}_{2}$ よるあのだ」を米国は認め, 排出を減らすための 研究に合意した。

また，欧州・カナダの10か国は自らを「30\%クラブ」 之称し，欧州・北米の SOx排出量を現在より $30 \%$ 減少 させる行動をすでに開始している.

\section{2 森林と湖沼に見られる生態系の破脿}

このような酸性雨の被害は主に生態系の破壊という 形で現われている，北欧・北米での影響の実例を整理 すると，一つは土㙵の酸性化ならびに栄養分の溶出に 伴う森林被害であり，いま一つは湖沼水等の酸性化に 伴う魚介類の減少と重金属溶出による污染である.

北欧では, 1960年代後半において, pH 4〜 5の降雨 により森林の成長が $2 \sim 7 \%$ 減少し, 酸性化により湖 沼水の $\mathrm{pH}$ が低下し, 多くの魚類が死滅してしまった という.土壤の酸性化に関しては, 北欧諸国では酸性 の強いポドソル土壌が多いため, 雨水の酸性が強くな れば，直線的に生産力の低下に結びっくという側面も あるようである。

土㙵，水圈の $\mathrm{pH}$ が低下すると,りん酸イオンが溶 解しにくくなり, Al, Mnイオンが溶解しやすくなり, 酸性土壤は生物に必要な物質が欠乏し, 有害物質を過 剩に含むことになる。 また，土㙵の有機物の分解，土 塨呼吸, 酵素活性等が激減する。

西独では, 全森林面積の半分以上に, 異常の徵候が 出ており，樹木亿対する被害は年間 800 万ドルといわ れ，その他に 600 万ドルあの農作物被害があるとされ ている．樹木に対する被害の原因としては，前述のよ うに酸性雨により土壌から遊離した $\mathrm{Al}$ イオンが細い根 に害を与えることあるいは, 栄養塩が久そすることが 指摘されている.

さらに，米国・ニューヨーク州の湖で $\mathrm{pH}$ が 6.6 7.2 から 3.9 5.8 亿低下し, 魚類の $75 \%$ が被害を受け たとと, カナダのオンタリオ州の多くの湖では $\mathrm{pH}$ が 4.5 となり，魚はいなくなり藻の生育が貧弱になった 
こと，スウェーデンではカビの菌糸が湖底に拡がった こと,ノルウェーでは酸性化により金属類が溶出し, 水中のAlイオン濃度が上ったとと等が酸性雨の被害と して数多く報告されている。 それ以外に，建造物の被 害屯多く指摘されている.

\section{5. 我が国における酸性雨問題}

\section{1 「湿性大気污染」}

我が国の「酸性雨」問題は約15年前，関東地方で表 面化した。乙れは人体被害あるいは植物被害という形 で極めてドラマチックに登場した。

まず，昭和46年 9 月23日の夜，東京・代々木駅周辺 で霧雨が降り, 通行人が10数人, 目に刺されるような 痛みを感じたという。広域的には, 昭和48年 6 月, 静 岡, 山梨両県で霧雨が目にしみるとともに, 一部には のどの刺激やせき,さらにはネギ，タバコ，キュウリ， ナスの上部が茶褐色に枯れたと報告された。ささらに昭 和49年 7 月には杤木県を中心に関東一円に被害がひろ まり，被害を訴えた人は 3 万人を越えた。その後，昭 和50年 $5 \sim 7$ 月に関東一円で被害が発生したが, 以後, 際立った被害の報告例はない。

環境庁は，乙の「酸性雨による被害」の内容と特徵 から，「湿性大気污染」と銘うって種々の調查を開始 した. その後, 類似の雨水調査は北海道から九州まで 全国各地で行われている。

一方, 昭和 56 年 6 月に関東地方に強酸性の降雨があ り, 群馬県の前橋で $\mathrm{pH} 2.86$ という強い酸性を示し, 雨水中の污染物質の濃度も極めて高かった。 pH4未満 の強い酸性を示す降雨は，ほとんどの地方で年に数回 観測されており，データが蓄積されるにつれ，pH3未 満の降雨でさえ，そう珍らしいてとではなくなってき ている.

\section{2 我が国での酸性雨による生態系の破壊}

前述の我が国での酸性雨による“人体被害”を軽視す るわけにはいかないが，ある程度大気污染による急性 被害と同次元の問題あるいは類似の現象として把握し てもよさそうである。乙のような問題とは別に，今， 国際的に問題になっているのは，主に国境を越えた大 気污染物質の長距離輸送に基づく酸性雨の長期的・慢 性的曝露による生態系の破壊である. しかしながら, 我 が国の被害は定量化されていないだけかむしれないが, 北欧・北米で指摘されている森林被害, 水資源の被害 は今のとてろほとんど報告されていない.

大気の污染, 雨水の酸性化は北欧・北米なみに進行
していると考えられるのに, 北欧・北米のような生態 系への影響が報告されていない理由として次のような 点があげられ, その一部については, 実験的あるいは 理論的な検討が加えられつつある.

1 ）我が国の土壌は酸性に強く, 北欧・北米の酸性 雨に敏感な地質とかなり異っている．2）我が国の河 川の勾配が急で, 雨水から持ち込まれる污染物質が河 川に停滞することなく, すぐ海域まで運ばれる. 3) 我 が国の湖沼は, 北欧・北米の湖沼のような閉鎖系のも のが少なく, 湖沼水の交換が速い等. また, 別の指摘 としては, 我が国の湖沼は, $\mathrm{HCO}_{3}$-による緩衝作用が 維持される段階であり, あるバランスを越えると急激 に酸性化し, 死の湖になる可能性があり, 今そのよう な剣が峰にあるのかもしれないと言われている．同じ 緩衝作用は土壌についてああてはまるが, 生態系への 影響は蓄積量によって決まるため, 現在の降下量以外 に1960～70年代の降下量が大きい意味をむってくる.

一方, 我が国の脱硫技術の進歩等による大気污染の 程度の違いを指摘する向き屯ある.

最近, 関東地方で, 酸性雨による「杉枯れ」が指摘 され調査が開始されている。 あし，てれが酸性雨によ る被害の一種であると実証されることにであなれば, 我が国の酸性雨問題は新しい局面を迎えることにもな る.また，酸性雨は大気污染が本質的に有している現 象の一つであるてとを考えれば，仮に「杉枯れ」が光 化学オキシダントを含む大気污染の影響によるもので あっても，同様の意味を持つものと思われる.

さらに, 一部では,「松くい虫」の被害についても, その責任の一端は大気污染と酸性雨にあるとの指摘も あり, 注目される.

\section{3 我が国の雨水性状の特徴}

それでは, 我が国の雨水性状の特徵はどのようなと ころにあるのであろうか. 関東地方で “被害”が報告さ れた1970年頃から, 我が国の多くの地点で主に容量別 分取法による測定が行われてきた。 そして，蓄積され てきたデータを解析すると, 次のようにまとめること ができる。

1 ) 我が国の都市部周辺の雨水の $\mathrm{pH}$ は主に $3 \sim 6$ の範囲に出現し, 平均值は 4.5 に近い(図-3). 観測さ れた $\mathrm{pH}$ の最低值は 2.6 である. $\mathrm{pH}$ 平均值は雨水の 採取法によっても，平均値の算出方法によっても異な るから注意が必要である.

2 ) $\mathrm{pH}$ の季節的変動は不明であるが, 夏期に低い $\mathrm{pH}$ を有する降雨の出現率が高い. また, 平均值で見 
の, 年度, 地域によるバラッキがある。また，夏期を た場合も，夏期の方が冬期よりやや低い傾向あるもの 中心として, 雨水の酸性化に及ぼすNOx系污染物質の 影響は大きい。な技，乙のような季節的変動は，米国 と我が国では必らずしも一致していない。

3) 乾性降下物む含め一か月単位で採取するデポジ ット・ゲージ法による $\mathrm{pH}$ の経年的な低下傾向は一部 の地域で見られたが，雨水のみを採取してきたての 10 年間のデータでは, 明確な $\mathrm{pH}$ の低下傾向は示されて いない。

$4 ）$ 雨水中の $\mathrm{SO}_{4}{ }^{2-}$ 濃度は季節的にも地域的にも変 動は小さいが, $\mathrm{NO}_{3}$-濃度の变動は大きい。

5 ）一雨内の雨水中成分濃度は, 降雨量の増加之之 屯に減少し, 特に $\mathrm{NO}_{3}{ }^{-}, \mathrm{Na}^{+}, \mathrm{Cl}^{-}$の減少量は大き

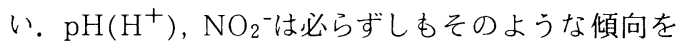
示さない. 都市部の雨水の $\mathrm{pH}$ 降雨初期に巾広い値を 示すが, 降雨量が増加すると, 一定の值に収束する傾 向がある.

6 ）主に測定されている10種足らずのイオンで, 雨 水中のアニオンとカチオンのバランスはほぼとれてお り, てれらの主成分によって雨水の性状が決められて いる.

7 ) 都市部の雨水の污染は, $\mathrm{NH}_{4}+{ }^{+} \mathrm{SO}_{4}{ }^{2-}$ による よりは, $\mathrm{NO}_{3}{ }^{-}$や $\mathrm{H}^{+}$により正確に評価される傾向があ る. また, $\mathrm{pH}$ と導電率との関係加ら雨水の地域特性 を示しうる。

$8)$ 雨水中の $\mathrm{Ca}^{2+}$ イオンは都市部で高く, 污染の 一つの指標となりそうであるが, $\mathrm{NH}_{4}{ }^{+}$ととあに酸性 を中和する役割を説明するには，まだデー夕不足であ る.

9 ）都市部の背後地の雨水でも, $\mathrm{NH}_{4}{ }^{+}$等の成分は 都市部なみの濃度で出現する地域が多い, また, 背後 地でも $\mathrm{pH}$ の低い地域が多い.

10）大気中の粒子状物質は降雨により除去されるが, その除去率は化学成分によって異なる. $\mathrm{NO}_{3}$-ならび に海塩粒子に含まれる成分の除去率は大きい。

11）SOx 等は降雨時, 濃度が減少するが, NOxは見 かけ上, 増加傾向を示すことが多い. 乙の現象は, 化 学反応によって説明しうる.

\section{6. まとめ}

全国各地で多くの酸性雨調查が行なわれてきたが, 酸性雨現象を解明するのに必要な地上デー夕はまだま だ不足だと言える。雨水の $\mathrm{pH}$ は年々低下しているの
かという問題に十分答えられるデータを見つけるのは 困難である.

雨水の酸性化により, 我が国でも生態系への影響が 起きているのかよ゙うか判断することは大切なととであ るが, それ以前に, 雨水が人為的原因により污染され, 酸性化しているてとだけで，すでに問題であると言っ ても過言でないように思われる。

どういう過程で雨水が酸性化されるかは別として, 雨水を酸性化しているのは, 主に化石燃料の燃焼に伴 う $\mathrm{SOx}$ であり, NOxであり, かつその大気中での二次 的変化物である.

酸性雨の影響は長期的に蓄積されてから現われるて とが多いため, 被害が定量的に把握されてからでは, 対策を立てるには遅すぎるかむしれない.

我が国でも，乙れらの認識の上に立ち，統一的手法 で, 広域的に恒常的な雨水監視測定網を確立し，それ に基づいた長期的な対策を立てる必要がある.

\section{引用 文 献}

1) 玉置元則：我が国の雨水の化学的性状，環境技術， 14, 132 (1985)

2) 玉置元則: 大気の污染之雨水の酸性化（我が国の酸性雨 の現状と課題)，PPM，15(3)，2 (1984).

3）玉置元則, 他：大気中の窒素酸化物比よる雨水の質的変 化(大気の浄化と雨水の酸性化), 大気污染学会誌, 20 , $71(1985)$.

4 ）玉置元則, 他：雨水成分の分析法(基本操作と問題点), 環 境技術，14，462，574，611(1985)。

5 ）玉置元則：酸性雨測定法の問題点，環境技術，12，841 (1983).

6）玉置元則，他：わが国における雨水 $\mathrm{pH}$ の年平均値，環境 技術，15，188，215(1986).

7 ）荒木邦夫，他，北海道公害防止研究所報，12，59(1985).

8 ）今 武純, 他, 青森県公害調查事務所報, 7, 57(1985).

9）早狩敏夫, 他, 青森県公害センタ一所報, 6, 90(1983).

10）信太 稞，他，秋田県環境技術センタ一年報，11，82 (1985)；斉藤 学, 他, 同誌, 12，94(1986).

11）新潟県公害研究所，新潟県公害研究所業務年報，13，20 （1984）；新潟県環境保健部 : 新潟県湿性大気污染調査報告 書 (1986).

12）友部正志，他，茨城県公害技術センタ一年報，17，55 (1984).

13）杤木県公害研究所大気騒音部，杤木県公害研究所年報, 9, 4 (1985).

14）氏家淳雄, 他, 群馬県衛生公害研究所年報, 16,116 （1984）; 関口恭一, 他, 同誌，17，165（1985）；第26回 大気污染学会講演要旨集, p349 (1985)；K. Sekiguchi, Environmental Technology Letters, 6, 391 (1985). 
15）埼玉県公害センター，埼玉県公害センター年報，11，109 (1984)；水上和子，他，同誌，12，38(1985).

16）小山 功, 他, 東京都公害研究所年報, 90 (1985); 古明地 哲人, 他, 同誌, 94(1985), 13(1986).

17）神奈川県環境部：昭和59年度酸性雨測定結果報告(1985).

18）鶴田治雄, 他, 横浜市公害研究所報, 10，25(1985）；河 村太郎，第22回衛生化学技術協議会年会講演集，166 (1985).

19）清水源治, 他, 山梨県衛生公害研究所年報, 28, 50(1984).

20）鈴木恒雄, 他, 静岡県衛生環境センタ一報告, 27, 151 (1984).

21）北村守次, 他, 石川県衛生公害研究所年報, 21, 94 (1984), 同誌, 22, 98(1985).

22）伊藤光雄, 昭和59年度愛知県環境保全担当職員研 究発表 会資料, p 1 (1984); 伊藤光雄, 他, 愛知県公害調査セン 夕一所報, 13, 30(1985).

23）日本気像協会東海本部, 尾觜地域におりる降雨污れ調査 報告書(1983)。

24）山田豊, 他, 京都府衛生公害研究所年報, 29, 104 (1984).

25）田口圭介, 第26回大気污染学会講演要旨集, p331 (1985); 国川隆治, 他, 同誌, p335 (1985).

玉置元則, 他, 兵庫県公害研究所研究報告, 17, 1，95, 97(1985); 平木隆年, 他, 同誌, 17, 6(1985); 光木偉勝, 他, 同誌, 17, 42(1985); 玉置元則, 他, 大気污染学会 誌, 21, 132 (1986).

27）松本光弘, 他, 奈良県衛生研究所年報, 19，63(1985).

28）井川良幸, 他, 和歌山県衛生公害研究センター年報, 31, 29(1985).

29）重田勇夫，他，京都市公害センター年報， 6，61(1985)；
徳田純夫, 他, 同誌, 6, 78(1985).

30 ）松本光弘, 他, 第24回日本公衆衛生学会近畿地方会口演 要旨集, p145 (1985); 田中靖志, 他, 同誌, p146 (1985) ; 谷尾桂子, 他, 同誌, p147(1985).

$31 ）$ 豊沢澄治, 他, 岡山県環境保健センター年報, 9, 90 (1985).

32）山口幸裕，他，全国公害研協議会中四国支部第12回大気 部会研究発表会要旨集, p 1 (1985); 楠憲一, 他, 同誌, p 5 (1985)；大原真由美，同誌, p 9 (1985)；豊沢澄治， 同誌, p12(1985).

33）小西壽久, 他, 德島県保健環境センター年報, 3，95 (1985).

34）三木正信, 他, 香川県公害研究センター所報， 9, 97 (1984).

35）三谷美嶺雄，他，愛媛県公害技術センター所報， 6， 1 (1985)；楠 憲一, 他, 同誌, 7， 1 (1986).

36）川村速雄, 他, 高知県公害防止センター所報, 1，105 (1984).

37）吉村賢一郎，他，長崎県衛生公害研究所報， 25，91，97 (1983)；26, 130, 135 (1984).

38）井村義弘, 熊本県衛生公害研究所報, 14, 32(1984).

39）木村和義, 岡山大学農学研究, 60,39(1982).

40) 土器屋由紀子, 第26回大気污染学会講演要旨集, p330 (1985).

41）田中和郎, 他, 宮城県保健環境センタ一年報, 3，153 (1985).

42）押尾敏夫, 千葉県公害研究所研究報告， 16，（1），13 (1984).

43）小畑聡子，宮崎県公害センター年報，8・9, 80(1985). 